\title{
A Systematic Review and Meta-analysis of Diabetes Associated Mortality in Patients with COVID-19
}

\author{
Puneeta Gupta ${ }^{1}$, Meeta Gupta ${ }^{2}$, Neena KAtoch ${ }^{3}$, Ketan Garg $\left(\mathbb{D}^{4,}{ }^{4}\right.$ and Bhawna Garg ${ }^{5}$ \\ ${ }^{1}$ Department of Medicine, Acharya Shri Chander College of Medical Sciences and Hospital Jammu, Jammu, India \\ ${ }^{2}$ Department of Obst and Gynae, Acharya Shri Chander College of Medical Sciences and Hospital, Jammu, India \\ ${ }^{3}$ Department of Pharmacology, Army College of Medical Sciences, New Delhi, India \\ ${ }^{4}$ Kegan Path Labs, New Delhi, india \\ ${ }^{5}$ Delhi University, New Delhi, India \\ "Corresponding author: Kegan Path Labs, New Delhi, india. Email: drketanpath@gmail.com
}

Received 2021 January 24; Revised 2021 June 01; Accepted 2021 August 08.

\begin{abstract}
Context: Coronavirus disease 2019 (COVID-19) has been one of the deadliest pandemics in recent decade. The virus has specifically targeted the comorbid population in terms of mortality. The present systematic review and meta-analysis aimed to determine the overall mortality and diabetes-associated mortality in COVID-19 patients.

Methods: To obtain the related data, six databases, including Pubmed, Embase, MEDLINE, Web of Science, Google Scholar, and DOAJ, were searched. The full-texts of articles presenting the data of COVID-19 mortality and diabetes-associated mortality were screened and retrieved. Statistical analysis was performed using the Stata (version 13). The odds ratio (OR) of mortality in diabetic patients was calculated with $95 \%$ confidence interval (CI). Random-effects model was used to synthesize data for the relevant outcomes. Heterogeneity was evaluated using I2 statistic. Forest plots visually showed the effect estimates of the included studies. We used funnel plots to evaluate potential publication bias. A two tailed $\mathrm{P}<0.05$ was considered as statistically significant.

Results: A total of 35 studies with 25,934 patients were finally included for meta-analysis. The pooled prevalence of diabetes mellitus in patients with COVID-19 was $16.8 \%(\mathrm{n}=4381)$. The overall mortality seen in all the studies was $12.81 \%(\mathrm{n}=3159)$, and diabetesassociated mortality was $22.14 \%(\mathrm{n}=970)$. The pooled analysis of included studies showed that diabetes mellitus had a significantly higher mortality rate $(22.14 \%$ vs. $12.81 \%, \mathrm{P}<0.05)$ with higher odds of death (pooled OR 1.83, 95\% CI: $1.61-2.05)$. The funnel plot was symmetric, thereby indicating a low risk of publication bias.

Conclusions: In conclusion, the presence of diabetes was associated with a significantly increased risk of mortality in patients admitted to the hospital with COVID-19. Thus, this subpopulation must be continuously monitored for glycemic levels, coagulation abnormalities, and inflammatory surge.
\end{abstract}

Keywords: COVID-19, Diabetes, Mortality

\section{Context}

The pandemic nature of coronavirus disease 2019 (COVID-19) has taken a heavy toll in the world, with almost 1.8 million deaths within a year. The subtle flu-like nature of the infection has deceived the population in terms of severity and mortality. Although there is a vaccination drive worldwide, the emerging new strains of COVID-19 has put the success of this drive at risk (1).

The clinical manifestation of the disease has been heterogeneous. The reports have been varied in terms of respiratory symptoms, dermatological symptoms, gastrointestinal symptoms, hematological disturbances, and neurological breakdowns. Furthermore, patients with comor- bidities such as diabetes, hypertension, and cardiac disease have been found to be at a significantly higher risk of hospital admissions, severe disease, and mortality (2). The disease originated in China, and according to the statement of the Centers for Disease Control and Prevention (CDC), $2.3 \%$ of COVID-19 mortality was seen in critical patients (3).

Diabetes is one of the commonest occurring lifestyle diseases worldwide, which is associated with multi-system damage in the long run. It is one of the arms of the complex branch of metabolic syndrome $\mathrm{X}$, which carries with itself numerous other chronic conditions. The susceptibility of COVID-19 infection increases in patients with diabetes as their immune functions is significantly decreased. 
Literature reports a diabetes prevalence of $7.87 \%-20 \%$ in COVID-19 patients (4-7). Studies have shown that it is one of the predictors of poor prognosis and mortality among the patients with COVID-19 (8). Moreover, the association of diabetes with adverse outcomes has also been observed in other human coronaviruses like severe acute respiratory syndrome (SARS) and Middle East respiratory syndrome (MERS) (9).

Various underlying mechanisms have been proposed for the substantially increased risk of infection in diabetes as follows: (1) Increased inflammatory markers; (2) hypercoagulability; (3) unregulated inflammatory responses to viral infection; (4) decreased "viral clearance" due to low immunity; and (5) presence of other comorbidities like cardiovascular diseases $(2,9)$. Figure 1 shows the pathophysiological association of COVID-19 with diabetes.

After an individual is infected with COVID-19, the body initiates an innate immune response releasing a plethora of cytokines and inflammatory markers, thereby altering endothelial cells structure and function, altered insulin delivery, and insulin resistance (10). Chen et al. (4) further added the occurrence of liver damage impairing one's ability to utilize glucose, causing a surge in the blood glucose levels. Molecular studies have shown that angiotensin converting enzyme 2 (ACE2) (11) is also one of the targets of coronavirus, leading to islet cell damage of the pancreas (12). This hyperglycemia is exaggerated in diabetics causing more oxidative stress, vascular damage, and multiorgan damage, including heart and kidneys.

The present meta-analysis aimed to determine the association of diabetes with mortality in COVID-19 patients. Our results may help in providing substantial evidence, thus laying a platform for prevention and control of diabetes in the growing pandemic of COVID-19.

\section{Methods}

To enlist the articles investigating diabetes-associated mortality in patients with COVID-19, searching the databases was conducted on December 24, 2020. The final search was updated on December 31, 2020. All the related studies were retrieved in their summary format for screening.

\subsection{Search Strategy}

The articles were searched on Pubmed, Embase, MEDLINE, Web of Science, Google Scholar, and DOAJ databases.

The keywords and their MeSH words were used in the search, which included diabetes (all fields), diabetes mellitus (MeSH), diabetes insipidus (MeSH), outcome (all field), admitted (all field), hospitalization (all field), severity (all field), mortality (all field), COVID-19, SARS-CoV-2 (MeSH), severe acute respiratory syndrome coronavirus $2(\mathrm{MeSH})$, $\mathrm{NCOV}(\mathrm{MeSH})$, and $2019 \mathrm{NCOV}(\mathrm{MeSH})$.

The search was done in the advanced mode using the Boolean operator "OR" and "AND”. The final advanced search builder showed: $(((C(()(((($ Diabetes) OR (diabetes mellitus)) OR(diabetes insipidus)) AND (outcome)) OR (admitted)) OR (hospitalization)) OR (severity)) AND (mortality)) AND (COVID-19)) OR (SARS-CoV-2)) OR (Severe Acute Respiratory Syndrome Coronavirus 2)) OR (NCOV)) OR (2019 NCOV).

We screened the free full-text of articles written in English language and conducted on humans.

\subsection{Inclusion Criteria}

We included case-control/cohort studies conducted on COVID-19 patients, as well as the studies representing the data of COVID-19 mortality and diabetes-associated mortality.

\subsection{Exclusion Criteria}

The following cases were excluded from the study: systematic reviews, editorials, meta-analysis, and review articles (narrative); studies from which the odds risk for diabetes-associated mortality could not be determined; duplicate studies reporting same results; and studies with a 50\% matching data from a single center.

\subsection{Reviewing Process}

The studies were independently reviewed by two authors (P.G and M.G). Any discrepancy was resolved after discussing the issue with two other authors (K.G and N.K). The full texts of all eligible articles were retrieved and assessed. The full-text of all included studies was available in open access, and in cases where only abstract was available, the article was not included.

\subsection{Outcomes}

The primary outcome of the study was (1) the incidence of mortality in patients with COVID-19 and (2) pooled diabetes-associated mortality risk in patients with COVID19. 

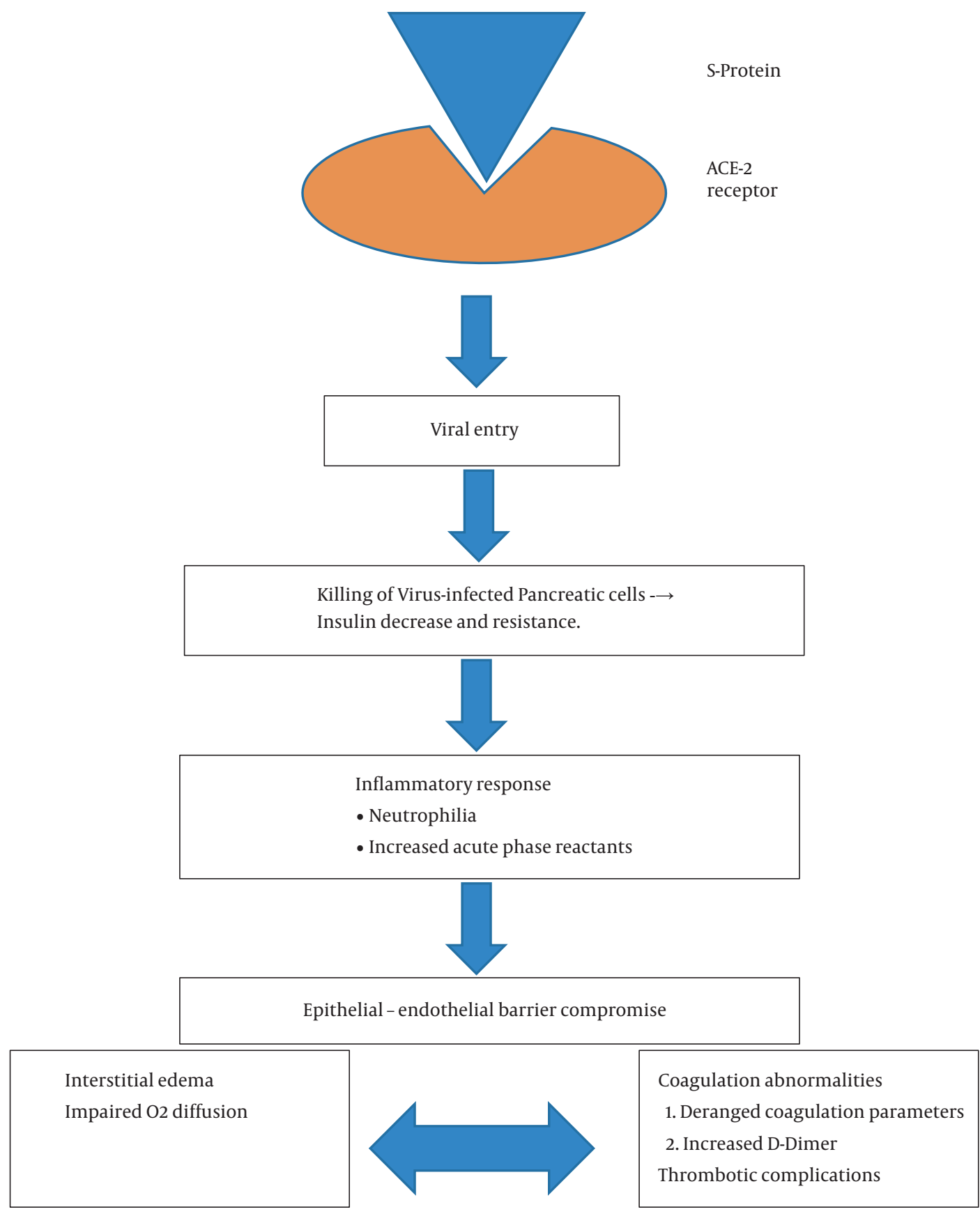

Figure 1. Pathophysiological association of COVID-19 with diabetes

\subsection{Data Extraction and Quality Assessment}

The data extraction was done independently by two authors (KG and BG). A Microsoft Excel sheet was prepared to record the outcomes of the included studies. The extracted parameters from the studies included the last name of au- thor (s), year of publication, location, total patients, age, gender, total mortality, proportion of patients with diabetes, and diabetes-associated mortality. The quality of the articles was adjudged by Newcastle-Ottawa Quality Assessment scale (NOS). This tool scores the studies on the basis 
of patient selection, patient comparability, and outcomes with a score ranging from 0 to 9 . The total score of $>7$ is considered as good quality (13).

\subsection{Statistical Analysis}

Statistical analysis was performed using the Stata (version 13). The most common measures of effect used for dichotomous data were the odds ratio (OR). The OR of mortality in diabetes mellitus patients was calculated with $95 \%$ confidence interval (CI). The studies were weighted as per the sample size to reflect the value of its evidence. It is important to recognize the smaller studies as they contribute less to the estimates of overall effect.

Random-effects models was used to synthesize data for the relevant outcomes with the assumption that distribution of effects exists, resulting in heterogeneity among study results, known as $\tau 2$. Heterogeneity was evaluated using $\mathrm{I}^{2}$ statistic. This is desirable because of the strong assumption that the effect of interest is frequently untenable in all studies.

A meta-analysis was conducted for the included studies in terms of subjects involved, interventions, and outcomes to provide a meaningful summary. Forest plots were made, which visually showed effect estimates of the included studies. Funnel plots and Egger's test were used to evaluate potential publication bias. A two tailed $\mathrm{P}<0.05$ was considered as statistically significant.

\section{Results}

The flow of studies in our meta-analysis is depicted in Figure 2. A total of 35 studies with 25,934 patients were finally included for meta-analysis (9,14-47). Among them, 23 studies were conducted in China (20-23, 25-31, 33, 34, 38-47), and 12 were conducted outside China (9, 14-19, 24, 32, 35-37). The study characteristics are shown in Table 1.

The pooled prevalence of diabetes mellitus in patients with COVID-19 was $16.8 \%(n=4381)$. The overall mortality seen in all the studies was $12.81 \%(n=3159)$, and diabetesassociated mortality was $22.14 \%(n=970)$.

Among the 12 studies conducted outside China, seven studies $(9,14,15,17,24,32,35)$ reported a significantly increased risk of diabetes-associated mortality, but five studies $(16,18,19,36,37)$ failed to show a statistical association of diabetes with mortality. The 12 studies carried a weightage of 59.59\% with an OR of 1.95 (95\% CI 1.66-2.24) for mortality in diabetes with COVID-19. The heterogeneity in the studies was significantly high $\left(\mathrm{I}^{2}=80.3 \%, \mathrm{P}<0.0001\right)$, but all the studies were of high quality as per the NOS scale. The studies value was adjusted as per their weightage, as shown in the forest plot (Figure 3).

In 23 studies conducted in China, 13 studies (20-22, 24, $29,33,34,38-40,43)$ reported a significantly increased risk of diabetes-associated mortality, but 12 studies (23, 25-28, $30,31,41,42,44-46)$ only found an increased risk, which failed to cross the statistical boundaries. The 23 Chinese studies carried a weightage of $40.41 \%$ with an OR of 1.65 (95\% CI 1.3 - 2) for mortality in diabetes with COVID-19. The studies had a low heterogeneity $\left(\mathrm{I}^{2}=0.0 \%, \mathrm{P}=0.803\right)$, and all the studies were of high quality as per the NOS scale. The studies' values were adjusted as per their weightage. The forest plot has been presented in Figure 3.

The pooled analysis of 35 studies showed that diabetes mellitus had a significantly higher mortality rate $(22.14 \%$ vs. $12.81 \%, \mathrm{P}<0.05$ ) with higher odds of death (pooled OR 1.83, 95\% CI: 1.61 - 2.05). The subgroup analyses in different locations showed similar results $(\mathrm{P}=0.195)$ (Figure 3 ).

\subsection{Publication Bias}

The NOS scale showed that all studies were of good quality, and no study remarkably affected the pooled mortality(Table 2). The funnel plot was symmetric, with Egger's test showing a P-value of 0.268 , thereby indicating a low risk of publication bias (Figure 4).

\section{Discussion}

This is one of the first meta-analysis which used all the studies published in 2020, thereby encompassing a large sample size for evaluation. The results confirmed that the prevalence of diabetes was high (16.8\%), and it carries an increased risk of mortality in patients with COVID-19 (OR = 1.83, 95\% CI: 1.61 - 2.05). This was in line with the recent review by Pinedo-Torres et al. (48) who showed a prevalence of 100.42 per 1000 COVID-19 patients (95\% CI: 77.85 - 125.26, $\left.\mathrm{I}^{2}=67.94 \%\right)$ in SARS-Cov-2.

Among the 35 included studies, the increased OR in 17 studies failed to reach a statistical significance $(16,18,19,25$ $28,30,31,36,37,41,42,44-46)$. This might be due to the adjustment with respect to other comorbidities.

The findings have been concordant with the metaanalysis of Shang et al. (2), reporting an OR of 2.21 for diabetes-associated mortality.

Another study accounted diabetes for a high mortality in COVID-19, that is, 40\% (49).

Also another meta-analysis by Huang et al. (50), coroborated with our study reporting an RR of 2.12 for diabetes associated mortality. 


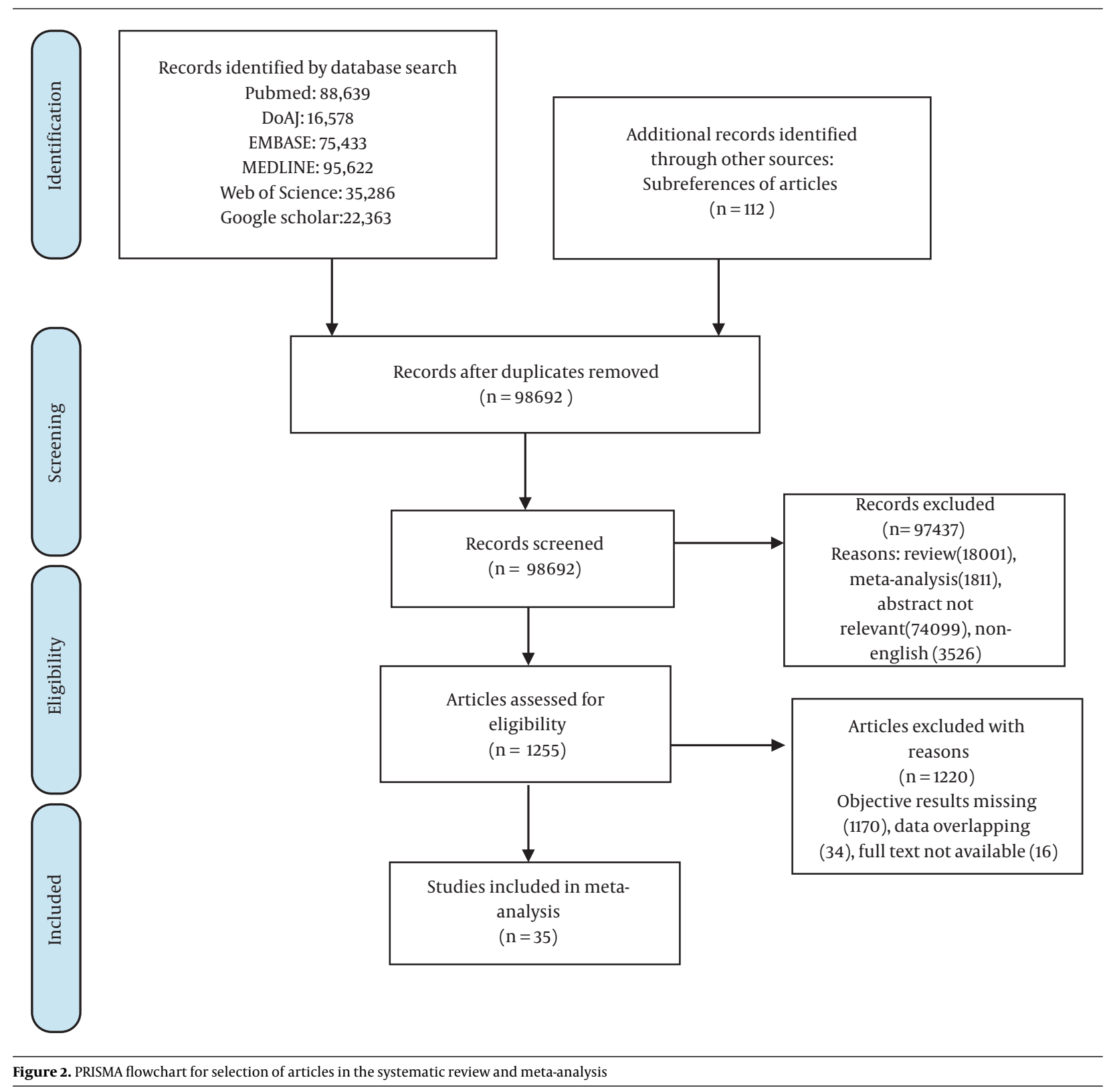

Diabetes is one of the comorbid conditions found in the elderly patients getting infected with COVID-19. Its prevalence among COVID-19 patients has been on an increase in the last few months (9). One of the meta-analysis portrayed that a pooled prevalence of diabetes mellitus among the patients with COVID-19 was $14.34 \%$ (51). The underlying factors in diabetes mellitus that may affect the mortality remain wide. Carrasco-Sanchez et al. (52), in a retrospective multicenter review, showed that hyperglycemia was an independent risk factor for mortality irrespective of the pre-existing diabetes (HR $=1.5$, 95\% CI: 1.31 -
1.73 for blood glucose $>180 \mathrm{mg} / \mathrm{dL}$ ). The debate on the antidiabetic medications conducive for use in COVID-19 among a plethora of oral hypoglycemics was solved by Cheng et al. (53), where the use of metformin showed no significantly increased risk of 28-days mortality [adjusted HR 1.65, 95\% CI: $0.71-3.86, \mathrm{P}=0.247$ ), which might be associated with reduction in inflammation. However, the use of metformin was associated with an increased risk of acidosis and derangement of kidney functions, which increased hospital admissions. Li et al. (33) compared the clinical characteristics of diabetic and nondiabetic COVID-19 patients. Com- 


\begin{tabular}{|c|c|c|c|c|c|c|c|}
\hline Author & Year & $\begin{array}{l}\text { Diabetic } \\
\text { Mortality }\end{array}$ & $\begin{array}{l}\text { Total } \\
\text { Mortality }\end{array}$ & $\begin{array}{l}\text { Diabetic } \\
\text { Non-mor tality }\end{array}$ & $\begin{array}{l}\text { Total } \\
\text { Non-mor tality }\end{array}$ & ES $(95 \% \mathrm{Cl})$ & $\begin{array}{l}\% \\
\text { Weight }\end{array}$ \\
\hline \multicolumn{8}{|l|}{ Outside of China } \\
\hline Abdullah A, et al. & 2020 & 24 & 60 & 73 & 357 & $2.59(1.46,4.62)$ & 1.98 \\
\hline Alberto $M$, et al. & 2020 & 157 & 460 & 224 & 1766 & $3.57(2.81,4.53)$ & 6.69 \\
\hline Arjun SY, et al. (Development Set) & 2020 & 90 & 313 & 518 & 3528 & $2.35(1.80,3.50)$ & 6.85 \\
\hline Austin $\mathrm{R}$, et al. & 2020 & 14 & 35 & 23 & 46 & $0.67(0.27,1.60)$ & 11.20 \\
\hline Chung SM, et al. & 2020 & 5 & 6 & 24 & 104 & $16.67(1.86,149.66)$ & 0.00 \\
\hline Ishan $P$, et al. & 2020 & 105 & 310 & 478 & 1889 & $2.09(1.56,2.81)$ & 1268 \\
\hline Mohamad N, et al. & 2020 & 11 & 239 & 102 & 2725 & $1.24(0.66,2.34)$ & 7.02 \\
\hline Reza S, et al. & 2020 & 2 & 9 & 14 & 104 & $1.84(0.35,9.75)$ & 022 \\
\hline Moon et al, & 2020 & 94 & 211 & 676 & 5096 & $5.25(3.96,6.97)$ & 2.18 \\
\hline Mir ani et al, & 2020 & 38 & 102 & 52 & 283 & $2.64(1.60,4.36)$ & 2.60 \\
\hline Bhatti et al, & 2020 & 1 & 5 & 25 & 98 & $0.73(0.08,6.84)$ & 0.43 \\
\hline Alguwaihes et al. & 2020 & 61 & 77 & 239 & 362 & $120(0.70,2.30)$ & 7.74 \\
\hline Subtotal (I-squared $=80.3 \%, p=0.000)$ & & & & & & $1.95(1.66,2.24)$ & 59.59 \\
\hline \multicolumn{8}{|l|}{ China } \\
\hline Cao JL, et al. & 2020 & 6 & 17 & 5 & 85 & $8.73(2.28,33.46)$ & 0.02 \\
\hline Chen $F$, et al. & 2020 & 21 & 82 & 93 & 578 & $1.80(1.04,3.09)$ & 4.71 \\
\hline Chen $\mathrm{T}$, et al. & 2020 & 24 & 113 & 23 & 161 & $1.62(0.86,3.04)$ & 4.17 \\
\hline Deng $Y$, et al. & 2020 & 17 & 109 & 9 & 116 & $2.20(0.93,5.16)$ & 1.11 \\
\hline Du RH, et al. & 2020 & 6 & 21 & 27 & 158 & $1.94(0.69,5.45)$ & 0.87 \\
\hline Fu L, etal. & 2020 & 26 & 34 & 111 & 166 & $1.61(0.68,3.79)$ & 2.05 \\
\hline Gu T, et al. & 2020 & 26 & 94 & 46 & 181 & $1.12(0.64,1.97)$ & 11.20 \\
\hline Guan WJ (b), et al. & 2020 & 13 & 50 & 117 & 1540 & $427(2.21,8.26)$ & 0.54 \\
\hline Guo WN, et al. & 2020 & 4 & 9 & 33 & 165 & $3.20(0.81,1258)$ & 0.14 \\
\hline $\mathrm{He} \mathrm{XW}$, et al. & 2020 & 8 & 26 & 5 & 28 & $2.04(0.57,7.33)$ & 0.43 \\
\hline Wang $\mathrm{H}$, et al. & 2020 & 7 & 26 & 18 & 95 & $1.58(0.58,4.31)$ & 1.42 \\
\hline Luo XM, et al. & 2020 & 25 & 100 & 32 & 303 & $2.82(1.58,5.05)$ & 1.64 \\
\hline Shi $Q$, et al. & 2020 & 31 & 47 & 122 & 259 & $2.18(1.13,4.17)$ & 2.14 \\
\hline Wang DW(b), et al. & 2020 & 5 & 19 & 6 & 88 & $4.88(1.31,18.18)$ & 0.07 \\
\hline Wang $L$, et al. & 2020 & 11 & 65 & 43 & 274 & $1.09(0.53,2.26)$ & 6.62 \\
\hline Yan YL et al. & 2020 & 39 & 108 & 9 & 85 & $4.77(2.16,10.57)$ & 028 \\
\hline Yang XB, et al. & 2020 & 7 & 32 & 2 & 20 & $2.52(0.47,13.58)$ & 0.12 \\
\hline Zhang F, et al. & 2020 & 5 & 17 & 5 & 31 & $2.17(0.53,8.93)$ & 0.28 \\
\hline Zhang $J J(b)$, et al. & 2020 & 7 & 49 & 20 & 240 & $1.83(0.73,4.61)$ & 1.32 \\
\hline Zhou $F$, et al. & 2020 & 17 & 54 & 19 & 137 & $2.85(1.35,6.05)$ & 0.90 \\
\hline Wang et al, & 2020 & 3 & 25 & 64 & 638 & $2.99(1.07,8.66)$ & 0.34 \\
\hline Li et al, & 2020 & 11 & 18 & 65 & 181 & $10.82(1.89,61.74)$ & 0.01 \\
\hline Chen et al, & 2020 & 49 & 217 & 89 & 888 & $7.96(2.25,28.24)$ & 0.03 \\
\hline Subtotal (I-squared $=0.0 \%, p=0.803$ ) & & & & & & $1.65(1.30,2.00)$ & 40.41 \\
\hline \multicolumn{8}{|l|}{ Heterog eneity between groups: $p=0.195$} \\
\hline Overall (I-squared $=53.8 \%, p=0.000$ ) & & & & & & $1.83(1.61,2.05)$ & 100.00 \\
\hline
\end{tabular}

Figure 3. Forest plot for calculating the pooled diabetes-associated risk of mortality

pared to nondiabetics, diabetics were older, with higher levels of D-dimer, glycemic levels, and blood urea at admission and lower levels of oxygen saturation, lymphocyte counts, and plasma albumin; these parameters were labeled as important in conferring a higher mortality ( $\mathrm{P}$ $<0.05$ ). The possible role of hypercoagulability, as an underlying mechanism has been reported in the studies by Cheng et al. (53) and Chen et al. (21).

The results of the current study and few previous meta-analysis studies showed that diabetes can increase the risk of mortality in COVID-19 patients, thus warranting a strict glycemic control, regular insulin infusions, pre-admissions HbA1c check, and compliance to the antidiabetic medications till the pandemic is controlled. This has been regularly enforced by expert panels from American Diabetes Association (9), Chinese Diabetes Society (54), the US CDC, Korean Diabetes Association (9), and the European Society of Endocrinology (55).
Since we are entering into the phase of vaccination, the control of inflammatory surge under the background of weakened immunity (as seen in diabetes) needs further research. Although vaccination drive has started, the current clinical management for the diabetes should be continuously advised to the susceptible population.

This study had some limitations. First, the confounding variables such as duration of diabetes, ongoing medications, blood glucose levels, and HbA1c levels were not assessed. Second, due to an initial surge in cases in China, it is possible that few studies have reported overlapping patients. Third, the study included only hospitalized patients with a high case fatality, but the routine patients with diabetes who went unnoticed could not be taken into account. This might have led to the overestimation of diabetesassociated mortality in studies. Fourth, the study design in most of the studies was retrospective case-control, which might cause an attrition bias. Future prospective and ran- 


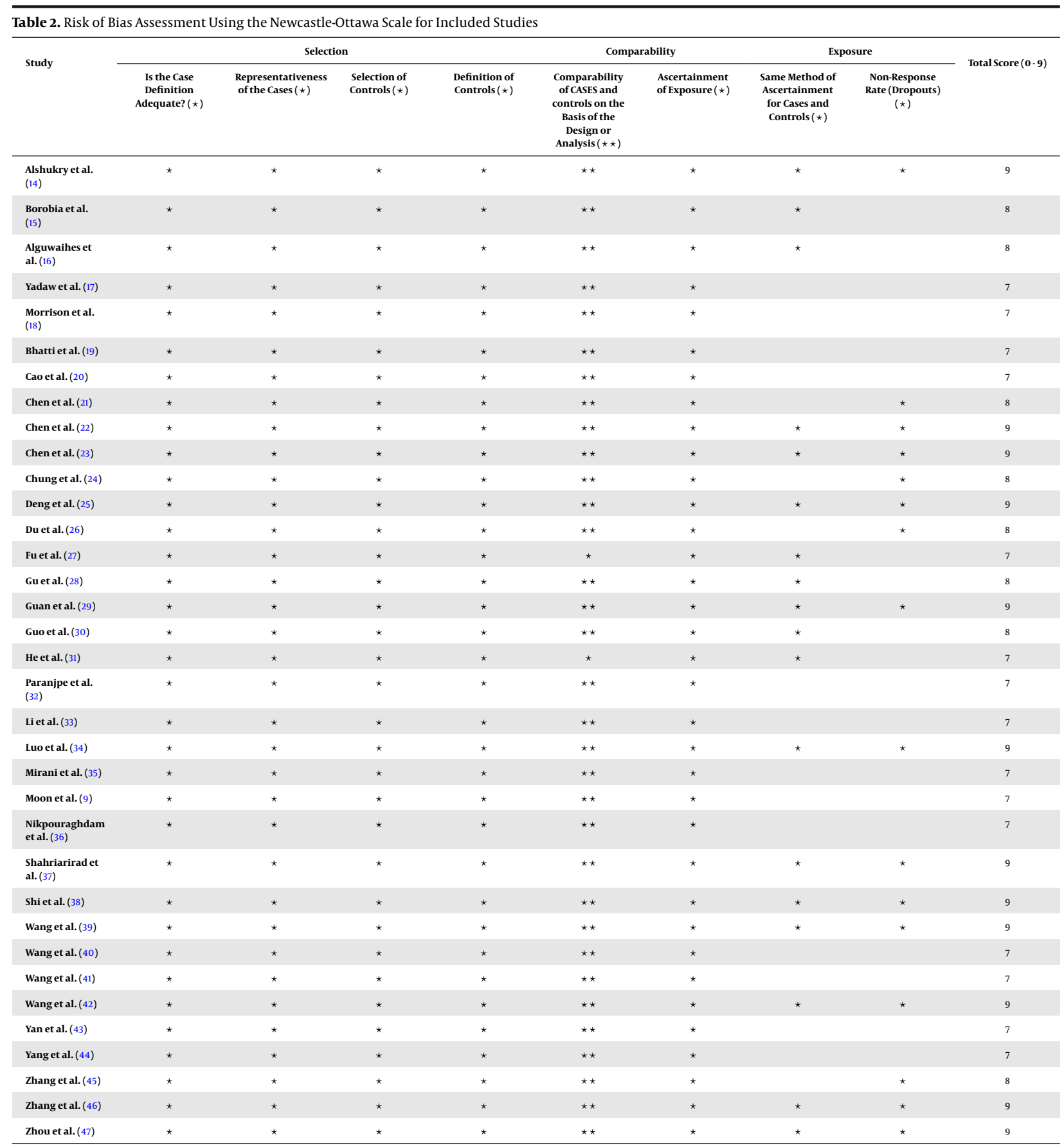

domized studies must be conducted to annul the confounding bias. Last, the research articles that were not free were excluded from the study.

\section{Conclusions}

In conclusion, the results of meta-analysis studies published worldwide during 2020 showed that the presence of diabetes is associated with a significantly increased risk of mortality in patients admitted to the hospital with COVID-19. The pooled OR for diabetes-associated mortal- 


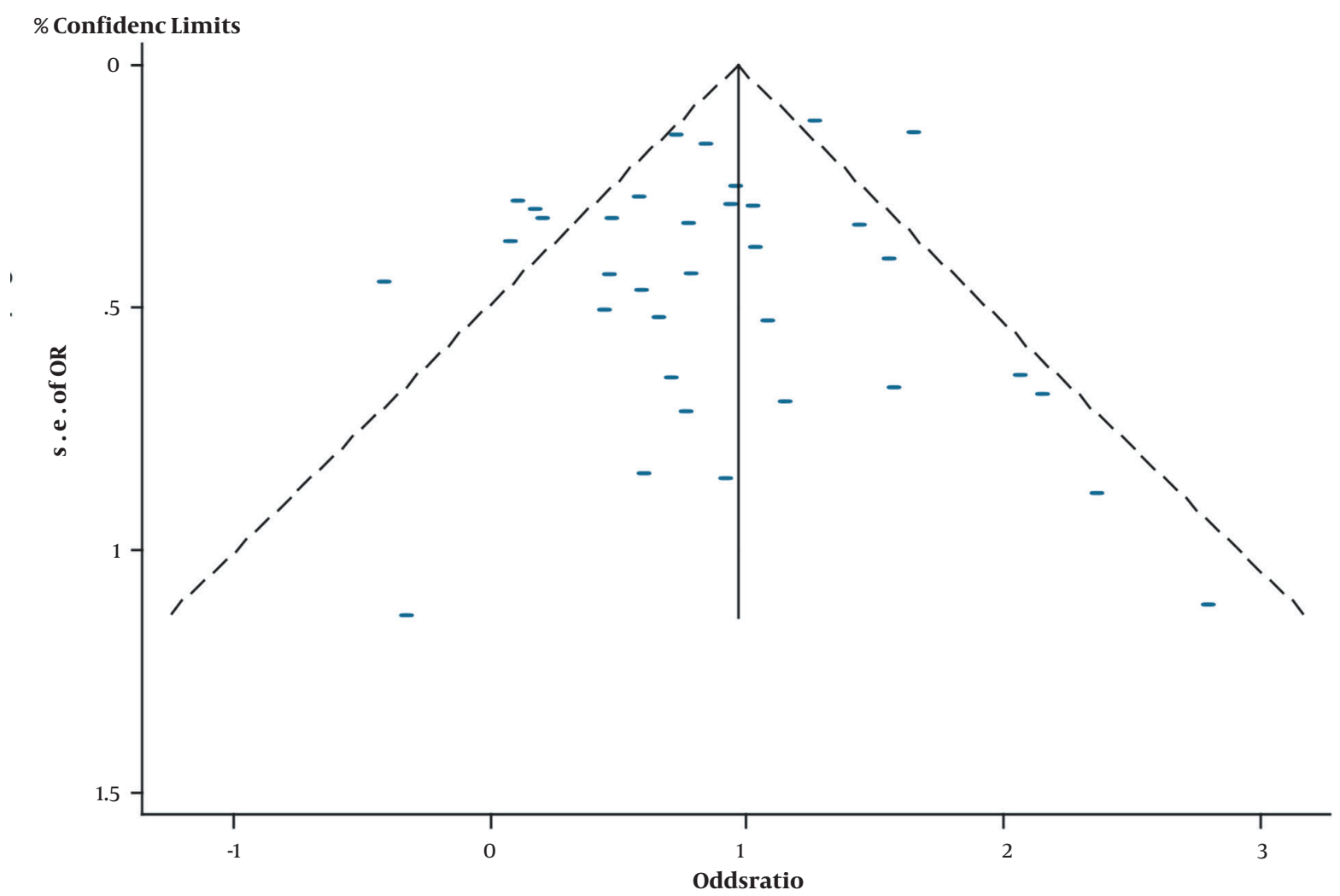

Figure 4. Funnel plot

ity was 1.83 , which was significantly higher than the overall COVID-19 mortality. Thus, considering the vulnerability for adverse outcomes, the subpopulation of diabetes must be continuously monitored for glycemic levels, coagulation abnormalities, and inflammatory surge in the event of COVID-19 admission. Besides, hospitals must stick to a strict diabetes management protocol for better care of COVID-19 patients.

\section{Footnotes}

Authors' Contribution: Study concept and design: PG and MG. Acquisition of data: P.G., M.G., K.G., and N.K. Analysis and interpretation of data: BG and KG. Drafting of the manuscript: KG and NK. Critical revision of the manuscript for important intellectual content: MG and PG. Statistical analysis: BG and KG. Administrative, technical, and material support: KG and NK. Study supervision: MG and PG.

Conflict of Interests: None to be declared.
Funding/Support: No external sources of funding.

\section{References}

1. Ozma MA, Maroufi P, Khodadadi E, Kose S, Esposito I, Ganbarov $\mathrm{K}$, et al. Clinical manifestation, diagnosis, prevention and control of SARS-CoV-2 (COVID-19) during the outbreak period. Infez Med. 2020;28(2):153-65. [PubMed: 32275257].

2. Shang L, Shao M, Guo Q, Shi J, Zhao Y, Xiaokereti J, et al. Diabetes Mellitus is Associated with Severe Infection and Mortality in Patients with COVID-19: A Systematic Review and Meta-analysis. Arch Med Res. 2020;51(7):700-9. doi: 10.1016/j.arcmed.2020.07.005. [PubMed: 32811670]. [PubMed Central: PMC7413048].

3. Wu Z, McGoogan JM. Characteristics of and Important Lessons From the Coronavirus Disease 2019 (COVID-19) Outbreak in China: Summary of a Report of 72314 Cases From the Chinese Center for Disease Control and Prevention. JAMA. 2020;323(13):1239-42. doi: 10.1001/jama.2020.2648. [PubMed: 32091533].

4. Chen N, Zhou M, Dong X, Qu J, Gong F, Han Y, et al. Epidemiological and clinical characteristics of 99 cases of 2019 novel coronavirus pneumonia in Wuhan, China: a descriptive study. Lancet. 2020;395(10223):507-13. doi: 10.1016/S0140-6736(20)30211-7. [PubMed: 32007143]. [PubMed Central: PMC7135076]. 
5. Wang D, Hu B, Hu C, Zhu F, Liu X, Zhang J, et al. Clinical Characteristics of 138 Hospitalized Patients With 2019 Novel CoronavirusInfected Pneumonia in Wuhan, China. JAMA. 2020;323(11):1061-9. doi: 10.1001/jama.2020.1585. [PubMed: 32031570]. [PubMed Central: PMC7042881].

6. Huang C, Wang Y, Li X, Ren L, Zhao J, Hu Y, et al. Clinical features of patients infected with 2019 novel coronavirus in Wuhan, China. Lancet. 2020;395(10223):497-506. doi: 10.1016/S0140-6736(20)30183-5. [PubMed: 31986264]. [PubMed Central: PMC7159299].

7. Javanmardi F, Keshavarzi A, Akbari A, Emami A, Pirbonyeh N. Prevalence of underlying diseases in died cases of COVID-19: A systematic review and meta-analysis. PLoS One. 2020;15(10). e0241265. doi: 10.1371/journal.pone.0241265. [PubMed: 33095835]. [PubMed Central: PMC7584167].

8. Li B, Yang J, Zhao F, Zhi L, Wang X, Liu L, et al. Prevalence and impact of cardiovascular metabolic diseases on COVID-19 in China. Clin Res Cardiol. 2020;109(5):531-8. doi: 10.1007/s00392-020-01626-9. [PubMed: 32161990]. [PubMed Central: PMC7087935].

9. Moon SJ, Rhee EJ, Jung JH, Han KD, Kim SR, Lee WY, et al. Independent Impact of Diabetes on the Severity of Coronavirus Disease 2019 in 5,307 Patients in South Korea: A Nationwide Cohort Study. Diabetes Metab J. 2020;44(5):737-46. doi: 10.4093/dmj.2020.0141. [PubMed: 33115212]. [PubMed Central: PMC7643598].

10. Fu Y, Cheng Y, Wu Y. Understanding SARS-CoV-2-Mediated Inflammatory Responses: From Mechanisms to Potential Therapeutic Tools. Virol Sin. 2020;35(3):266-71. doi: 10.1007/s12250-020-00207-4. [PubMed: 32125642]. [PubMed Central: PMC7090474].

11. Walls AC, Park YJ, Tortorici MA, Wall A, McGuire AT, Veesler D. Structure, Function, and Antigenicity of the SARS-CoV-2 Spike Glycoprotein. Cell. 2020;181(2):281-292 e6. doi: 10.1016/j.cell.2020.02.058. [PubMed: 32155444]. [PubMed Central: PMC7102599].

12. Yang JK, Lin SS, Ji XJ, Guo LM. Binding of SARS coronavirus to its receptor damages islets and causes acute diabetes. Acta Diabetol. 2010;47(3):193-9. doi: 10.1007/s00592-009-0109-4. [PubMed: 19333547]. [PubMed Central: PMC7088164].

13. Stang A. Critical evaluation of the Newcastle-Ottawa scale for the assessment of the quality of nonrandomized studies in meta-analyses. Eur J Epidemiol. 2010;25(9):603-5. doi: 10.1007/s10654-010-9491-z. [PubMed: 20652370].

14. Alshukry A, Ali H, Ali Y, Al-Taweel T, Abu-Farha M, AbuBaker J, et al. Clinical characteristics of coronavirus disease 2019 (COVID19) patients in Kuwait. PLoS One. 2020;15(11). e0242768. doi: 10.1371/journal.pone.0242768. [PubMed: 33216801]. [PubMed Central: PMC7678995].

15. Borobia AM, Carcas AJ, Arnalich F, Alvarez-Sala R, MonserratVillatoro J, Quintana M, et al. A Cohort of Patients with COVID-19 in a Major Teaching Hospital in Europe. J Clin Med. 2020;9(6). doi: 10.3390/jcm9061733. [PubMed: 32512688]. [PubMed Central: PMC7356883].

16. Alguwaihes AM, Al-Sofiani ME, Megdad M, Albader SS, Alsari MH, Alelayan A, et al. Diabetes and Covid-19 among hospitalized patients in Saudi Arabia: a single-centre retrospective study. Cardiovasc Diabetol. 2020;19(1):205. doi: 10.1186/s12933-020-01184-4. [PubMed: 33278893]. [PubMed Central: PMC7718833].

17. Yadaw AS, Li Y, Bose S, Iyengar R, Bunyavanich S, Pandey G. Clinical features of COVID-19 mortality: development and validation of a clinical prediction model. Lancet Digit Health. 2020;2(10):e516-25. doi: 10.1016/s2589-7500(20)30217-x.

18. Morrison AR, Johnson JM, Griebe KM, Jones MC, Stine JJ, Hencken $\mathrm{LN}$, et al. Clinical characteristics and predictors of survival in adults with coronavirus disease 2019 receiving tocilizumab. J Autoimmun. 2020;114:102512. doi: 10.1016/j.jaut.2020.102512. [PubMed: 32646770]. [PubMed Central: PMC7332925].
19. Bhatti R, Khamis AH, Khatib S, Shiraz S, Matfin G. Clinical Characteristics and Outcomes of Patients With Diabetes Admitted for COVID19 Treatment in Dubai: Single-Centre Cross-Sectional Study. JMIR Public Health Surveill. 2020;6(4). e22471. doi: 10.2196/22471. [PubMed: 33284130]. [PubMed Central: PMC7722483].

20. Cao J, Tu WJ, Cheng W, Yu L, Liu YK, Hu X, et al. Clinical Features and Short-term Outcomes of 102 Patients with Coronavirus Disease 2019 in Wuhan, China. Clin Infect Dis. 2020;71(15):748-55. doi: 10.1093/cid/ciaa243. [PubMed: 32239127]. [PubMed Central: PMC7184479].

21. Chen X, Chen Y, Wu C, Wei M, Xu J, Chao YC, et al. Coagulopathy is a major extrapulmonary risk factor for mortality in hospitalized patients with COVID-19 with type 2 diabetes. BMJ Open Diabetes Res Care. 2020;8(2). doi: 10.1136/bmjdrc-2020-001851. [PubMed: 33214191]. [PubMed Central: PMC7677866].

22. Chen F, Sun W, Sun S, Li Z, Wang Z, Yu L. Clinical characteristics and risk factors for mortality among inpatients with COVID-19 in Wuhan, China. Clin Transl Med. 2020;10(2). e40. doi: 10.1002/ctm2.40. [PubMed: 32508024]. [PubMed Central: PMC7300688].

23. Chen T, Wu D, Chen H, Yan W, Yang D, Chen G, et al. Clinical characteristics of 113 deceased patients with coronavirus disease 2019: retrospective study. BMJ. 2020;368:m1091. doi: 10.1136/bmj.m1091. [PubMed: 32217556]. [PubMed Central: PMC7190011].

24. Chung SM, Lee YY, Ha E, Yoon JS, Won KC, Lee HW, et al. The Risk of Diabetes on Clinical Outcomes in Patients with Coronavirus Disease 2019: A Retrospective Cohort Study. Diabetes Metab J. 2020;44(3):40513. doi: 10.4093/dmj.2020.0105. [PubMed: 32602272]. [PubMed Central: PMC7332325].

25. Deng Y, Liu W, Liu K, Fang YY, Shang J, Zhou L, et al. Clinical characteristics of fatal and recovered cases of coronavirus disease 2019 in Wuhan, China: a retrospective study. Chin Med J (Engl). 2020;133(11):1261-7. doi: 10.1097/CM9.0000000000000824. [PubMed: 32209890]. [PubMed Central: PMC7289311].

26. Du RH, Liang LR, Yang CQ, Wang W, Cao TZ, Li M, et al. Predictors of mortality for patients with COVID-19 pneumonia caused by SARS-CoV-2: a prospective cohort study. Eur Respir J. 2020;55(5). doi: 10.1183/13993003.00524-2020. [PubMed: 32269088]. [PubMed Central: PMC7144257].

27. Fu L, Fei J, Xiang H, Xiang Y, Tan Z, Li M, et al. Influence factors of death risk among COVID-19 patients in Wuhan, China: a hospital-based casecohort study. MedRxiv. 2020. doi: 10.1101/2020.03.13.20035329.

28. Gu T, Chu Q, Yu Z, Fa B, Li A, Xu L, et al. History of coronary heart disease increased the mortality rate of patients with COVID-19: a nested casecontrol study. BMJ Open. 2020;10(9). e038976. doi: 10.1136/bmjopen2020-038976. [PubMed: 32948572]. [PubMed Central: PMC7499679].

29. Guan WJ, Liang WH, He JX, Zhong NS. Cardiovascular comorbidity and its impact on patients with COVID-19. Eur RespirJ. 2020;55(6). doi: 10.1183/13993003.01227-2020. [PubMed: 32341104]. [PubMed Central: PMC7236831].

30. Guo W, Li M, Dong Y, Zhou H, Zhang Z, Tian C, et al. Diabetes is a risk factor for the progression and prognosis of COVID-19. Diabetes Metab Res Rev.2020. e3319. doi:10.1002/dmrr.3319. [PubMed: 32233013]. [PubMed Central: PMC7228407].

31. He XW, Lai JS, Cheng J, Wang MW, Liu YJ, Xiao ZC, et al. [Impact of complicated myocardial injury on the clinical outcome of severe or critically ill COVID-19 patients]. Zhonghua Xin Xue Guan Bing Za Zhi. 2020;48(6):456-60. Chinese. doi: 10.3760/cma.j.cn112148-2020022800137. [PubMed: 32171190].

32. Paranjpe I, Russak AJ, De Freitas JK, Lala A, Miotto R, Vaid A, et al. Clinical characteristics of hospitalized COVID-19 patients in New York City. medRxiv. 2020. doi: 10.1101/2020.04.19.20062117.

33. Li G, Deng Q, Feng J, Li F, Xiong N, He Q. Erratum to "Clinical 
Characteristics of Diabetic Patients with COVID-19". J Diabetes Res. 2021;2021:9756140. doi: 10.1155/2021/9756140. [PubMed: 34285921]. [PubMed Central: PMC8275428].

34. Luo X, Xia H, Yang W, Wang B, Guo T, Xiong J, et al. Characteristics of patients with COVID-19 during epidemic ongoing outbreak in Wuhan, China. medRxiv. 2020. doi: 10.1101/2020.03.19.20033175.

35. Mirani M, Favacchio G, Carrone F, Betella N, Biamonte E, Morenghi E, et al. Impact of Comorbidities and Glycemia at Admission and Dipeptidyl Peptidase 4 Inhibitors in Patients With Type 2 Diabetes With COVID-19: A Case Series From an Academic Hospital in Lombardy, Italy. Diabetes Care. 2020;43(12):3042-9. doi: 10.2337/dc20-1340. [PubMed: 33023989].

36. Nikpouraghdam M, Jalali Farahani A, Alishiri G, Heydari S, Ebrahimnia M, Samadinia H, et al. Epidemiological characteristics of coronavirus disease 2019 (COVID-19) patients in IRAN: A single center study. J Clin Virol. 2020;127:104378. doi: 10.1016/j.jcv.2020.104378. [PubMed: 32353762]. [PubMed Central: PMC7172806].

37. Shahriarirad R, Khodamoradi Z, Erfani A, Hosseinpour H, Ranjbar K, Emami Y, et al. Epidemiological and clinical features of 2019 novel coronavirus diseases (COVID-19) in the South of Iran. BMC Infect Dis. 2020;20(1):427. doi: 10.1186/s12879-020-05128-x. [PubMed: 32552751]. [PubMed Central: PMC7301075].

38. Shi Q, Zhang X, Jiang F, Zhang X, Hu N, Bimu C, et al. Clinical Characteristics and Risk Factors for Mortality of COVID-19 Patients With Diabetes in Wuhan, China: A Two-Center, Retrospective Study. Diabetes Care.2020;43(7):1382-91. doi:10.2337/dc20-0598. [PubMed:32409504].

39. Wang D, Yin Y, Hu C, Liu X, Zhang X, Zhou S, et al. Clinical course and outcome of 107 patients infected with the novel coronavirus, SARS-CoV-2, discharged from two hospitals in Wuhan, China. Crit Care. 2020;24(1):188. doi: 10.1186/s13054-020-02895-6. [PubMed: 32354360]. [PubMed Central: PMC7192564].

40. Wang X, Liu Z, Li J, Zhang J, Tian S, Lu S, et al. Impacts of Type 2 Diabetes on Disease Severity, Therapeutic Effect, and Mortality of Patients With COVID-19. J Clin Endocrinol Metab. 2020;105(12). doi: 10.1210/clinem/dgaa535. [PubMed: 32979271]. [PubMed Central: PMC7543468].

41. Wang H, Lu Y, Lv Q, Wu X, Hu T, Wang K, et al. Progression, recovery and fatality in patients with SARS-CoV-2 related pneumonia in Wuhan, China: a single-centered, retrospective, observational study. medRxiv. 2020. doi: 10.1101/2020.05.12.20099739.

42. Wang L, Li X, Chen H, Yan S, Li D, Li Y, et al. Coronavirus Disease 19 Infection Does Not Result in Acute Kidney Injury: An Analysis of 116 Hospitalized Patients from Wuhan, China. Am J Nephrol. 2020;51(5):3438. doi: 10.1159/000507471. [PubMed: 32229732]. [PubMed Central: PMC7179524].

43. Yan Y, Yang Y, Wang F, Ren H, Zhang S, Shi X, et al. Clinical characteristics and outcomes of patients with severe covid-19 with diabetes. BMJ Open Diabetes Res Care. 2020;8(1). doi: 10.1136/bmjdrc-2020-001343. [PubMed: 32345579]. [PubMed Central: PMC7222577].

44. Yang X, Yu Y, Xu J, Shu H, Xia J, Liu H, et al. Clinical course and outcomes of critically ill patients with SARS-CoV-2 pneumonia in Wuhan, China: a single-centered, retrospective, observational study. Lancet Respir Med. 2020;8(5):475-81. doi: 10.1016/S2213-2600(20)300795. [PubMed: 32105632]. [PubMed Central: PMC7102538].

45. Zhang F, Yang D, Li J, Gao P, Chen T, Cheng Z, et al. Myocardial injury is associated with inhospital mortality of confirmed or suspected COVID-19 in Wuhan, China: A single center retrospective cohort study. medRxiv. 2020. doi: 10.1101/2020.03.21.20040121.

46. Zhang JJ, Cao YY, Tan G, Dong X, Wang BC, Lin J, et al. Clinical, radiological, and laboratory characteristics and risk factors for severity and mortality of 289 hospitalized COVID-19 patients. Allergy. 2021;76(2):533-50. doi: 10.1111/all.14496. [PubMed: 32662525]. [PubMed Central: PMC7404752].

47. Zhou F, Yu T, Du R, Fan G, Liu Y, Liu Z, et al. Clinical course and risk factors for mortality of adult inpatients with COVID-19 in Wuhan, China: a retrospective cohort study. Lancet. 2020;395(10229):105462. doi: 10.1016/S0140-6736(20)30566-3. [PubMed: 32171076]. [PubMed Central: PMC7270627].

48. Pinedo-Torres I, Flores-Fernandez M, Yovera-Aldana M, GutierrezOrtiz C, Zegarra-Lizana P, Intimayta-Escalante C, et al. Prevalence of Diabetes Mellitus and Its Associated Unfavorable Outcomes in Patients With Acute Respiratory Syndromes Due to Coronaviruses Infection A Systematic Review and Meta-Analysis. Clin Med Insights Endocrinol Diabetes. 2020;13:1179551420962500. doi: 10.1177/1179551420962495. [PubMed: 33177910]. [PubMed Central: PMC7592335].

49. Li X, Wang L, Yan S, Yang F, Xiang L, Zhu J, et al. Clinical characteris tics of 25 death cases with COVID-19: A retrospective review of medical records in a single medical center, Wuhan, China. Int J Infect Dis 2020;94:128-32. doi: 10.1016/j.ijid.2020.03.053. [PubMed: 32251805] [PubMed Central: PMC7128884].

50. Huang I, Lim MA, Pranata R. Diabetes mellitus is associated with increased mortality and severity of disease in COVID-19 pneumonia - A systematic review, meta-analysis, and meta-regression. Diabetes Metab Syndr. 2020;14(4):395-403. doi: 10.1016/j.dsx.2020.04.018. [PubMed: 32334395]. [PubMed Central: PMC7162793].

51. Mantovani A, Byrne CD, Zheng MH, Targher G. Diabetes as a risk factor for greater COVID-19 severity and in-hospital death: A meta-analysis of observational studies. Nutr Metab Cardiovasc Dis. 2020;30(8):123648. doi: 10.1016/j.numecd.2020.05.014. [PubMed: 32571616]. [PubMed Central: PMC7258796].

52. Carrasco-Sanchez FJ, Lopez-Carmona MD, Martinez-Marcos FJ, PerezBelmonte LM, Hidalgo-jimenez A, Buonaiuto V, et al. Admission hyperglycaemia as a predictor of mortality in patients hospitalized with COVID-19 regardless of diabetes status: data from the Spanish SEMI-COVID-19 Registry. Ann Med. 2021;53(1):103-16. doi 10.1080/07853890.2020.1836566. [PubMed: 33063540]. [PubMed Central: PMC7651248].

53. Cheng X, Liu YM, Li H, Zhang X, Lei F, Qin JJ, et al. Metformin Is Associated with Higher Incidence of Acidosis, but Not Mortality, in Individuals with COVID-19 and Pre-existing Type 2 Diabetes. Cell Metab. 2020;32(4):537-547 e3. doi: 10.1016/j.cmet.2020.08.013. [PubMed: 32861268]. [PubMed Central: PMC7439986].

54. Diabetes Branch of Chinese Medical Association. Management sug gestions for patients with diabetes and novel coronavirus pneumonia. Chin J Diabetes Mellitus. 2020;12:73-5.

55. Puig-Domingo M, Marazuela M, Giustina A. COVID-19 and endocrine diseases. A statement from the European Society of Endocrinology. Endocrine. 2020;68(1):2-5. doi: 10.1007/s12020-020-02294-5. [PubMed: 32279224]. [PubMed Central: PMC7150529]. 
Table 1. Study Characteristics

\begin{tabular}{|c|c|c|c|c|c|c|c|c|}
\hline Study & Location & $\begin{array}{l}\text { N, Study } \\
\text { Design }\end{array}$ & $\begin{array}{l}\text { Diabetes } \\
\text { popula- } \\
\text { tion, No. } \\
(\%)\end{array}$ & Age, $y$ & Males, \% & $\begin{array}{c}\text { Total } \\
\text { Mortality }\end{array}$ & $\begin{array}{l}\text { Diabetes } \\
\text { Mortality }\end{array}$ & $\begin{array}{c}\text { Diabetes as } \\
\text { mortality } \\
\text { risk (OR } \\
\text { with 95\% } \\
\text { CI) }\end{array}$ \\
\hline $\begin{array}{l}\text { Alshukry et al. } \\
(14)\end{array}$ & $\begin{array}{l}\text { Jaber Al-Ahmad Hospital, } \\
\text { Kuwait. }\end{array}$ & $417, \mathrm{R}$ & $97(23.3)$ & $47(32,60)$ & $262(63)$ & 60 & 24 & $\begin{array}{c}\text { (OR 2.59; } \\
95 \% \mathrm{CI}, 1.46- \\
4.62)\end{array}$ \\
\hline $\begin{array}{l}\text { Alguwaihes et al. } \\
\text { (16) }\end{array}$ & Riyadh, Saudi Arabia & $439, \mathrm{R}$ & $300(68.34)$ & 55 & $300(68.3)$ & 77 & 61 & $\begin{array}{c}\text { (HR: } 1.2,95 \% \\
\text { CI: } 0.7-2.3)\end{array}$ \\
\hline $\begin{array}{l}\text { Yadaw et al. } \\
\text { (Development } \\
\text { Set)(17) }\end{array}$ & $\begin{array}{l}\text { Mount Sinai Hospital } \\
\text { System, New York }\end{array}$ & $3841, \mathrm{P}$ & $608(15.8)$ & $56.2 \pm 19$ & $2125(55.3)$ & 313 & 90 & $\begin{array}{c}(\text { OR } 2.35 ; 95 \% \\
\text { CI, } 1.80-3.5)\end{array}$ \\
\hline $\begin{array}{l}\text { Morrison et al. } \\
\text { (18) }\end{array}$ & $\begin{array}{l}\text { Five hospital health } \\
\text { systems in Michigan }\end{array}$ & $81, \mathrm{R}$ & $37(45.7)$ & $64(58,71)$ & $56(69.1)$ & 35 & 14 & $\begin{array}{c}\text { (OR 0.67; } \\
95 \% \mathrm{CI}, 0.27- \\
1.6)\end{array}$ \\
\hline Bhatti et al. (19) & Dubai & $103, \mathrm{OC}$ & $26(25.24)$ & 54 & $69(66.9)$ & 5 & 1 & $\begin{array}{c}\text { (OR: } 0.73, \\
95 \% \mathrm{CI} \\
0.078-6.84 \text { ) }\end{array}$ \\
\hline Cao et al. (20) & Zhongnan Hospital & $102, \mathrm{R}$ & $11(10.8)$ & $54(37,67)$ & $53(52)$ & 17 & 6 & $\begin{array}{c}\text { (OR 8.73; 95\% } \\
\text { CI, 2.28 - } \\
33.46)\end{array}$ \\
\hline Chen et al. (21) & Wuhan (China) & $1105, \mathrm{R}$ & $138(12.49)$ & 56.3 & $597(54)$ & 217 & 49 & $\begin{array}{c}\text { (HR: } 7.96 ; \\
95 \% \text { CI } 2.25- \\
28.24)\end{array}$ \\
\hline Chen et al. (22) & $\begin{array}{l}\text { The Central Hospital of } \\
\text { Wuhan }\end{array}$ & $660, \mathrm{R}$ & $114(17.3)$ & $55(34,68)$ & $295(44.7)$ & 82 & 21 & $\begin{array}{c}\text { (OR } 1.80 ; 95 \% \\
\text { CI, 1.04 - } \\
3.09)\end{array}$ \\
\hline Chen et al. (23) & Tongji hospital & $274, \mathrm{R}$ & $47(17)$ & $62(44,70)$ & $171(62)$ & 113 & 24 & $\begin{array}{c}\text { (OR } 1.62 ; 95 \% \\
\text { CI, } 0.86- \\
3.04)\end{array}$ \\
\hline Deng et al. (25) & $\begin{array}{l}\text { Hankou and Cai-dian } \\
\text { branch of Tongji } \\
\text { Hospital }\end{array}$ & $225, \mathrm{R}$ & $26(11.6)$ & $\begin{array}{l}\text { death: } 69 \\
(62,74) ; \\
\text { recovered: } \\
40(33,57)\end{array}$ & $124(55.1)$ & 109 & 17 & $\begin{array}{c}\text { (OR 2.20; } \\
95 \% \text { CI, } 0.93 \\
-5.16)\end{array}$ \\
\hline Du et al. (26) & $\begin{array}{l}\text { Wuhan Pulmonary } \\
\text { Hospital }\end{array}$ & $179, \mathrm{P}$ & $33(18.4)$ & $57.6 \pm 13.7$ & $97(54.2)$ & 21 & 6 & $\begin{array}{c}\text { (OR } 1.94 ; 95 \% \\
\text { CI, } 0.69- \\
5.45)\end{array}$ \\
\hline Fu et al. (27) & $\begin{array}{l}\text { Union Hospital of } \\
\text { Huazhong University of } \\
\text { Science and Technology }\end{array}$ & $200, P$ & $137(68.5)$ & $\begin{array}{c}39(19.5 \%) \\
\text { cases older } \\
\text { than } 70 \\
\text { years }\end{array}$ & $99(49.5)$ & 34 & 26 & $\begin{array}{c}\text { (OR } 1.61 ; 95 \% \\
\text { CI, } 0.68- \\
3.79)\end{array}$ \\
\hline Gu et al. (28) & Mainland China & 275, CC & $72(26.2)$ & $66.4 \pm 14.5$ & $173(62.9)$ & 94 & 26 & $\begin{array}{c}\text { (OR } 1.12 ; 95 \% \\
\text { CI, } 0.64- \\
1.97)\end{array}$ \\
\hline Guan et al. (29) & 575 hospitals in China & $1590, \mathrm{R}$ & $130(8.2)$ & $48.9 \pm 16.3$ & $904(57.3)$ & 50 & 13 & $\begin{array}{c}\text { (OR 4.27; } \\
95 \% \text { CI, 2.21 - } \\
8.26)\end{array}$ \\
\hline Guo et al. (30) & Wuhan Union hospital & $174, \mathrm{R}$ & $37(21.1)$ & $59(49,67)$ & $76(43.7)$ & 9 & 4 & $\begin{array}{c}\text { (OR 3.20; } \\
95 \% \mathrm{CI}, 0.81- \\
12.58)\end{array}$ \\
\hline He et al. (31) & $\begin{array}{l}\text { The Sino-French New City } \\
\text { Branch of Tongji hospital }\end{array}$ & $54, \mathrm{R}$ & $13(24.1)$ & $68(59,74)$ & $34(63)$ & 26 & 8 & $\begin{array}{c}\text { (OR 2.04; } \\
95 \% \mathrm{CI}, 0.57- \\
7.33)\end{array}$ \\
\hline $\begin{array}{l}\text { Paranjpe et al. } \\
(32)\end{array}$ & $\begin{array}{l}5 \text { major hospitals of New } \\
\text { York city }\end{array}$ & $2199, \mathrm{OC}$ & $583(26.5)$ & $65(54,76)$ & $1293(58.8)$ & 310 & 105 & $\begin{array}{c}\text { (OR 2.09; } \\
95 \% \mathrm{CI}, 1.56- \\
2.81)\end{array}$ \\
\hline
\end{tabular}




\begin{tabular}{|c|c|c|c|c|c|c|c|c|}
\hline Li et al. (33) & Wuhan (China) & $199, \mathrm{R}$ & $76(38.19)$ & 63 & $89(44.7)$ & 18 & 11 & $\begin{array}{c}\text { OR: } 10.816 ; \\
1.895-61.741)\end{array}$ \\
\hline Luo et al. (34) & $\begin{array}{l}\text { Eastern Campus of } \\
\text { Renmin Hospital, Wuhan } \\
\text { University }\end{array}$ & $403, \mathrm{R}$ & $57(14.1)$ & $56(39,68)$ & $193(47.9)$ & 100 & 25 & $\begin{array}{c}\text { (OR 2.82; } \\
95 \% \mathrm{CI}, 1.58- \\
5.05)\end{array}$ \\
\hline Mirani et al. (35) & Italy & $385, \mathrm{OC}$ & $90(23.38)$ & 66 & $257(66.7)$ & 102 & 38 & $\begin{array}{c}\text { (OR: } 2.638 \\
95 \% \mathrm{CI}, 1.597 \\
-4.356)\end{array}$ \\
\hline Moon et al. (9) & South Korea & $5307, \mathrm{P}$ & $770(14.51)$ & 56 & $2043(38.5 \%)$ & 211 & 94 & $\begin{array}{c}\text { (OR: } 5.253 \text {, } \\
95 \% \text { CI, } 3.957 \\
-6.973)\end{array}$ \\
\hline $\begin{array}{l}\text { Nikpouraghdam } \\
\text { et al. }(36)\end{array}$ & $\begin{array}{l}\text { Baqiyatallah hospital in } \\
\text { Tehran, Iran }\end{array}$ & $2964, \mathrm{R}$ & $113(3.8)$ & $56(46,65)$ & $1955(66.0)$ & 239 & 11 & $\begin{array}{c}\text { (OR } 1.24 ; 95 \% \\
\text { CI, } 0.66- \\
2.34)\end{array}$ \\
\hline $\begin{array}{l}\text { Shahriarirad et } \\
\text { al. (37) }\end{array}$ & $\begin{array}{l}\text { Five hospitals affiliated } \\
\text { by the Shiraz University }\end{array}$ & $113, \mathrm{R}$ & $16(14.2)$ & 53.75 & $71(62.8)$ & 9 & 2 & $\begin{array}{c}\text { (OR } 1.84 ; 95 \% \\
\text { CI, } 0.35- \\
9.75)\end{array}$ \\
\hline Shi et al. (38) & $\begin{array}{l}\text { Renmin Hospital and } \\
\text { Zhongnan Hospital of } \\
\text { Wuhan University }\end{array}$ & $306, \mathrm{R}$ & $153(50.0)$ & $\begin{array}{l}\text { No diabetes: } \\
65(56,72) \\
\text { diabetes: } 64 \\
(56,72)\end{array}$ & $150(49.0)$ & 47 & 31 & $\begin{array}{l}\text { (OR 2.18; 95\% } \\
\text { CI, } 1.13-4.17)\end{array}$ \\
\hline Wang et al. (39) & $\begin{array}{l}\text { Zhongnan Hospital of } \\
\text { Wuhan University and } \\
\text { Xishui People's Hospital }\end{array}$ & $107, \mathrm{R}$ & $11(10.3)$ & $51(36,65)$ & $57(53.3)$ & 19 & 5 & $\begin{array}{l}\text { (OR 4.88; } \\
95 \% \mathrm{CI}, 1.31- \\
\quad 18.18)\end{array}$ \\
\hline Wang et al. (40) & China & $663, \mathrm{R}$ & $67(10.11)$ & 58 & $321(48.4 \%)$ & 25 & 3 & $\begin{array}{c}\text { Poor } \\
\text { therapeutic } \\
\text { effect: (OR } \\
2.99 ; 95 \% \mathrm{CI} \text {, } \\
1.07-8.66)\end{array}$ \\
\hline Wang et al. (41) & Hankou Hospital & $121, \mathrm{R}$ & $25(20.7)$ & $59(46,67)$ & $66(54.6)$ & 26 & 7 & $\begin{array}{c}\text { (OR } 1.58 ; 95 \% \\
\text { CI, } 0.58- \\
4.31)\end{array}$ \\
\hline Wang et al. (42) & $\begin{array}{l}\text { Renmin Hospital of } \\
\text { Wuhan University }\end{array}$ & $339, \mathrm{OC}$ & $54(16.0)$ & $69(65,76)$ & $166(49.0)$ & 65 & 11 & $\begin{array}{c}\text { (OR 1.09; } \\
95 \% \text { CI, } 0.53- \\
2.26)\end{array}$ \\
\hline Yan et al. (43) & Tongji hospital & $193, \mathrm{OC}$ & $48(24.9)$ & $64(49,73)$ & $114(59.1)$ & 108 & 39 & $\begin{array}{c}\text { (OR 4.77; 95\% } \\
\text { CI, } 2.16- \\
10.57)\end{array}$ \\
\hline Yang et al. (44) & $\begin{array}{l}\text { Wuhan Jin Yin-tan } \\
\text { hospital }\end{array}$ & $52 \mathrm{R}$ & $9(17)$ & $59.7 \pm 13.3$ & $35(67)$ & 32 & 7 & $\begin{array}{c}\text { (OR 2.52; } \\
95 \% \text { CI, } 0.47 \\
-13.58)\end{array}$ \\
\hline Zhang et al. (45) & Wuhan No.1 Hospital & $48 \mathrm{R}$ & $10(20.8)$ & $70.6 \pm 13.4$ & $33(68.8)$ & 17 & 5 & $\begin{array}{c}\text { (OR 2.17; 95\% } \\
\text { CI, } 0.53- \\
8.93)\end{array}$ \\
\hline Zhang et al. (46) & $\begin{array}{l}\text { Zhongnan Hospital and } \\
\text { No.7 hospital of Wuhan }\end{array}$ & $289, \mathrm{R}$ & $27(9.3)$ & $57(22,88)$ & $154(53.3)$ & 49 & 7 & $\begin{array}{c}\text { (OR } 1.83 ; 95 \% \\
\text { CI, } 0.73- \\
4.61)\end{array}$ \\
\hline Zhou et al. (47) & $\begin{array}{l}\text { Jin Yin-tan hospital and } \\
\text { Pulmonary Hospital }\end{array}$ & $191, \mathrm{R}$ & $36(19)$ & $56(46,67)$ & $119(62)$ & 54 & 17 & $\begin{array}{c}\text { (OR 2.85; } \\
95 \% \mathrm{CI}, 1.35- \\
6.05)\end{array}$ \\
\hline
\end{tabular}

Abbreviations: CC, case control; OC, observational cross-sectional; P, prospective cohort; R, retrospective observational cohort. 